\title{
From Prototypical Stimuli to Iconographic Stimuli: The Power of Images in the Study of Social Representations
}

\author{
Ida Galli ${ }^{\otimes}$, Roberto Fasanelli $i$ \\ University of Naples Federico II, \\ 1 Vico Monte della Pietà, Naples, 80138, Italian Republic \\ $\checkmark$ idagalli@unina.it
}

\begin{abstract}
When we are interested in the image of a social object, we are interested in what individuals have perceived about that object, the ways in which they have interpreted those perceptions, and what they think about that object. Fully agreeing with the idea that the use of iconographic stimuli can enhance the traditional methods and techniques that are used to study any social representation, in this article, two techniques will be presented. The first, the prototypical stimuli technique, was proposed in the second half of the 1980s by Galli and Nigro. The second technique, iconographic stimuli, creatively integrate images and words in a single tool, was designed more recently to study the social representation of culture by Galli, Fasanelli, and Schember. Researches here reviewed clearly shows that the image has the great power to attract to itself the very objects depicted, a power that the word often does not possess. It is images that make people reflect, help them to think about issues concerning the fundamental aspects of everyday life. The work here presented, carried out in first person by the writer, as well as by all the other authors who are concentrating their efforts in this direction, only represents a starting point of reflection. New and more articulated studies will be able to support with heuristic evidence what so far seems to be configured as a suggestive hypothesis, which in any case will require a wider and shared interdisciplinary effort.
\end{abstract}

Key words: social representations, prototypical stimuli, iconographic stimuli, multimethods approach

\section{Introduction}

As Barale (2009) reminds us, the famous iconologist Aby Warburg was convinced that the distancing allowed by an image is a prerequisite for the capacity of reflection. In Warburg's opinion, thought needs a space - a space between the self and the object. The creation of distance between the self and the external world can be described as "the fundamental act of human civilization", that is, a kind of interval between the stimulus and the action or a pause between the impulse and the consequent behavior. For Warburg, the loss of this distance between signified and signifier, between observer and object, identifies the central problem

(C) Galli I., Fasanelli R., 2021

(c) (7) This work is licensed under a Creative Commons Attribution 4.0 International License This work is licensed under a Creative Comm
https://creativecommons.org/licenses/by/4.0/ 
of science or, rather, of the link between art and science, where the latter is always considered to be at a higher level than the former. As the author himself points out in the fragments of Symbolismus al Umfangsbestimmung, "The work of art is the result of the repeated effort, on the part of the subject, to establish a distance between himself and the object" (Warburg, 1896-1901. P. 23).

Science has always tried to establish a distance between itself and what ordinary people do on a daily basis, such as using a pictorial image to identify a deity or, more recently, looking for a known image to anchor an unknown and disturbing concept.

Serge Moscovici has devoted his scholarly career to understanding this complex interplay between science and common sense. Through the Social Representations Theory (SRT), he has offered an explanation for this constant and continuous work, carried out by social groups, aimed at finding the best way to prefigure, or rather refigure, any attempt to deal with a problem, a cataclysm or, contrarily, a joyful event for the community. This is what usually happens within the processes of the naturalization of cognitions, which help make new and unusual notions seem similar to other notions and other scientific names, giving them a "palpable" existence. Naturalization tends to provide an autonomous figurative model and a status of evidence for the complex reality of "common sense" (Moscovici, 1961. Pp. 316-317).

We often employ vivid images, aware as we are of their explanatory power: we look for them inside our minds to explain concepts or ideas that, because of their abstract nature, cannot be easily understood. We are also aware that the use of an image does not merely ensure the simplification of information, but it familiarizes us with a concept, correlating it with the knowledge that we have learned through listening in everyday life. Everyday language and common knowledge are particularly rich in their representational ability, precisely because they assimilate and complete the transformation from concept to image. The study of images, as pointed out by Abric (1987), has a long history in the psychological literature, although it mostly appears as a perceptual model, within which the image is seen as a reflection of the surrounding world, with a clear separation between subject and object. The interpretation of the image that we present here derives from the concept of representation and assumes, on the contrary, a constitutive relationship between subject and object. In these terms, the image is not a mere reflection of an object but the product of a complex relationship - whether real or imaginary, objective or symbolic - that the subject projects onto a specific object (Molinari, Emiliani, 1990).

In reflecting on the relationship between images and collective beliefs, Moliner (2008), inspired by Moscovici (1961), studied the role of icons as identifying tools of social representation, stating that iconography must be considered the source, medium, and product of representation. According to Moliner, when we are interested in the image of a social object, we are interested in how individuals perceive that object, the ways in which they have interpreted those perceptions, and what they think about that object. This is why "the notion of image as a phenomenon of collective opinion cannot be unrelated to the notions of visual image, mental image, and symbolic image" (Moliner, 1996. P. 111). Therefore, as it is, images must necessarily be part of that small nucleus (central core) of elements that gives rise to any social representation, as shown by scholars of Aix-enProvence University. 
According to de Rosa and Farr (2001), although images can be an important source of communication, scientific thought has often underestimated them, considering them a harbinger of errors and falsehoods. In the literature, in fact, the prejudice towards images is demonstrated by the scarce attention given to them by sociologists and social psychologists - this is a paradox for these disciplines in a society where visual information dominates written and spoken information in terms of impact. Only in developmental or clinical psychology, and of course in the psychology of the arts, does attention to figurative language, as well as to perception, testify to the existence of an interest in alternative forms of language to verbalcentrism.

In his comparative study of figurative and visual thinking, for example, Darras (1998 as cited in Moliner, 2016) proposes a useful taxonomy for classifying images, focusing on four main types: similis, which have a stronger relationship of analogy with their object; schémas, are images which take one or more figurative characters of the object, without it being necessary to include all the details that characterize it; iconotypes, which result in the repeated and recognized use of a given pattern; pictogrammes, coinciding with an iconotype validated by a community of users (Darras, 1998. P. 92). These consistently represent the figurative characteristics of each object, thus identifying the sociological or cultural specificity of individuals. It is important to note that objects represented through diagrams, iconotypes, and pictograms do not necessarily belong to the visibly perceptible physical world. This is true, for example, in the graphic representation of a process (the evolutionary stages of man), a system of relationships (the Catholic hierarchy), or a phenomenon (the seismogram). In any case, the diagram remains the only possible way to reproduce an image of the object, since it would be difficult to produce an analog image, a simile according to the previous terminology (Moliner, 2016). Reflecting on the relationship between images and collective beliefs, Moliner (2008) investigated the role of icons as tools for identifying a social representation, stating that iconography must be considered a source, means and product of a representation.

Starting from a reflection on the role that the image can play in overcoming the bottlenecks of "verbal exclusivity", we could begin to assert that the same word "image" contains within itself a wide variety of phenomena. Mitchell (2005) suggests a distinction between two English words: picture and image. In particular, he points out that picture is an iconographic representation, a particular form of form. Furthermore, as Moliner (2016) argues, image relates to the concrete objects that offer themselves to our perception. These objects exist independent of our perceptual identity. As stated by de Rosa and Farr (2001), within the human species, speech is a privileged channel for defining, objectifying, and constructing reality; however, reality cannot be defined exclusively through speech: images, sounds, and behaviors are other ways of generating and communicating 'multiform' (not necessarily complementary and, in some cases, antagonistic) aspects of social representations. For these reasons, it seems appropriate to explore social representation using methodologies and techniques that involve the use of iconographic, as well as verbal, stimuli. This is also in line with the constant exposure that complex images have undergone in recent years, transforming the myriad of icons on our devices, which identify and summarize objects, processes and emotions. 


\section{From prototypical stimuli to iconographic stimuli}

Fully agreeing with the idea that the use of iconographic stimuli can enhance the traditional methods and techniques that are used to study any social representation, two techniques will be presented below: the prototypical stimuli and iconographic stimuli used in a series of studies that have taken as their focus "power" and "culture".

The first, called the prototypical stimuli technique, was proposed in the second half of the 1980s by Galli and Nigro (Galli, Nigro, 1989).

At that time, the authors intended to study the social representation of "power", but they soon realized that a simple interview would not be enough to make the interviewees overcome the taboo inherent in the very idea of power. What was needed was a strategy that could overcome this impasse. This gave rise to the idea of enriching the interview with the presentation of 6 black and white photographs (Figure 1), created ad hoc, as prototypical stimuli; three of the photographs were related to dyadic power relationships (mother/son, husband/wife, doctor/ patient), and three were related to one-to-many power relationships (Pope/believers, university teacher/students, officer/troop). Each image represented an asymmetrical power situation about which respondents were asked to make judgments.
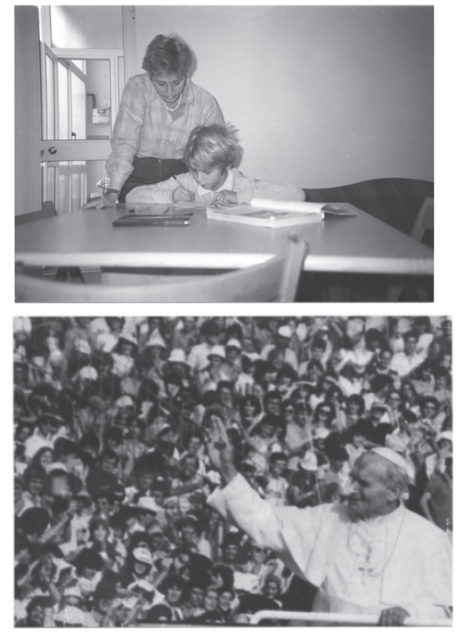
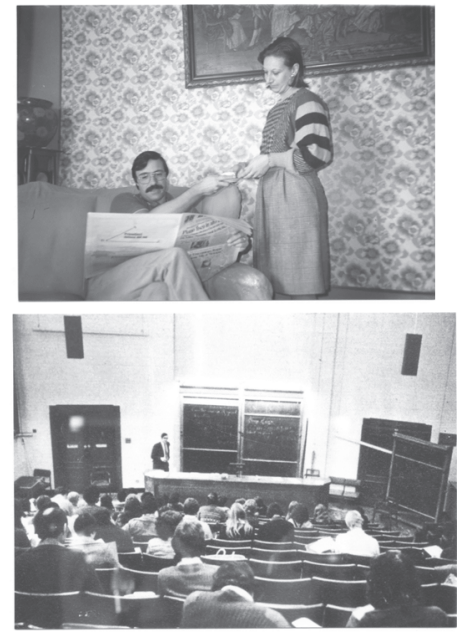

Figure 1. Prototypical stimuli (Galli, Nigro, 1989)
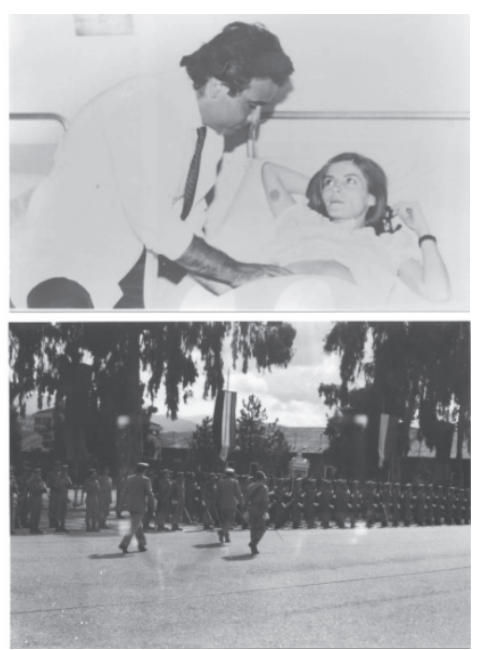

The descriptions and judgments made about the photographs allowed for a better understanding of how people represent themselves as either holding power or being subjected to it, as well as the relationships defined by the power situation more generally. At the end of the task, the respondents were asked to place the 6 photographs in hierarchical order from the one that most clearly expressed power to the one that expressed it the least. The main function of prototypical stimuli is to make "visible" certain manifestations that help define the object of representation so that the subjects' discourse moves from the abstract to the concrete: prototypical stimuli, in fact, induce subjects to confront specific situations. This technique can be advantageously used for the collection of both qualitative and quantitative information. In fact, prototypical stimuli can be used in 
the course of a qualitative interview, as well as within data collection tools that involve the use of scalar items. In the first case, the use of prototypical stimuli is particularly useful, first, because it helps reduce the incidence of those responses in terms of social desirability, which pollutes even the most sophisticated and well-structured questionnaires and interviews (Fasanelli et al., 2020; Galli et al., 2019). Second, by having subjects express their evaluation on any interval scale, it is possible to reconstruct in a very precise way the "attitude" component of the social representation one intends to study. Prototypical stimuli undoubtedly offer the advantage of allowing the transposition of the object of social representation from the abstract to the concrete. By making the object of representation visible, it is, in fact, possible to "force" the subject to confront it directly and to be, in the end, less evasive in expressing him or herself.

The research on power SRs, carried out using prototypical stimuli, was replicated in the first decade of the 2000s in an intercultural project financed by LEPS and directed by Moscovici, who oversaw the involvement of French, Indonesian, Mexican and Romanian colleagues. In this case, too, the technique showed its value. However, to avoid Eurocentric bias, the necessity of constructing ad hoc visual stimuli was highlighted, anchoring those stimuli to the stylistic features related to phenotypes, settings and ornaments characteristic of the cultures of reference in the data-construction context. The results of these reflections, impossible to adequately summarize here, are contained in the text edited by Ida Galli (2008): "Del potere e di altri dèmoni".

The second technique that creatively integrated images and words into a single tool was designed by Galli, Fasanelli, and Schember (2018) to study the social representation of culture. Inspired by prototypical stimuli, this data construction strategy was named iconographic stimuli.

The iconographic stimuli technique consists of asking a group of independent judges to provide a number of icons (functional to the objectives of the research being conducted) that represent, from their perspective, the object of study. The resulting icons (from physical or telematic archives or from ad hoc creations, both manual and computerized) are categorized into semantic areas and related categories using content analysis of the graphic materials. The result of this classification is then submitted to a group of judges. The judges have the preliminary task of eliminating all polysemic, duplicate or strongly similar images and, finally, of choosing the icon that best represents each of the identified semantic areas. The icons selected to be used as stimuli are those on which at least $70 \%$ of the judges agree. The set of icons thus selected is randomized and integrated into a questionnaire constructed in line with those used for the analysis of prototypicality and similarity. Basically, the instrument comprises the following: a section dedicated to the presentation of all the icons, each identified with a letter of the alphabet (Figure 2); a section dedicated to the explanation, by the participants, of the motivation that led them to the choice of each specific icon; and a section dedicated to the classification of the icons in hierarchical order of attributed importance (Fasanelli, Galli, Piscitelli, 2020; Galli, Fasanelli, 2020).

The goal of the iconographic stimuli technique is to explore an object of social representation using images situated in a communication process. The images 
do not necessarily have the same relationship to the object because they may be symbolic images, representing one thing and signifying something else. In contrast to pictograms, whose relationship to the object merges with the consensual recognition of certain figurative forms, the symbolic image derives its meaning from a system of correspondences, which goes far beyond the realm of mere representation: "In other words, images are translated and selected by individuals other than those for whom they are intended" (Moliner, 2016. P. 14).
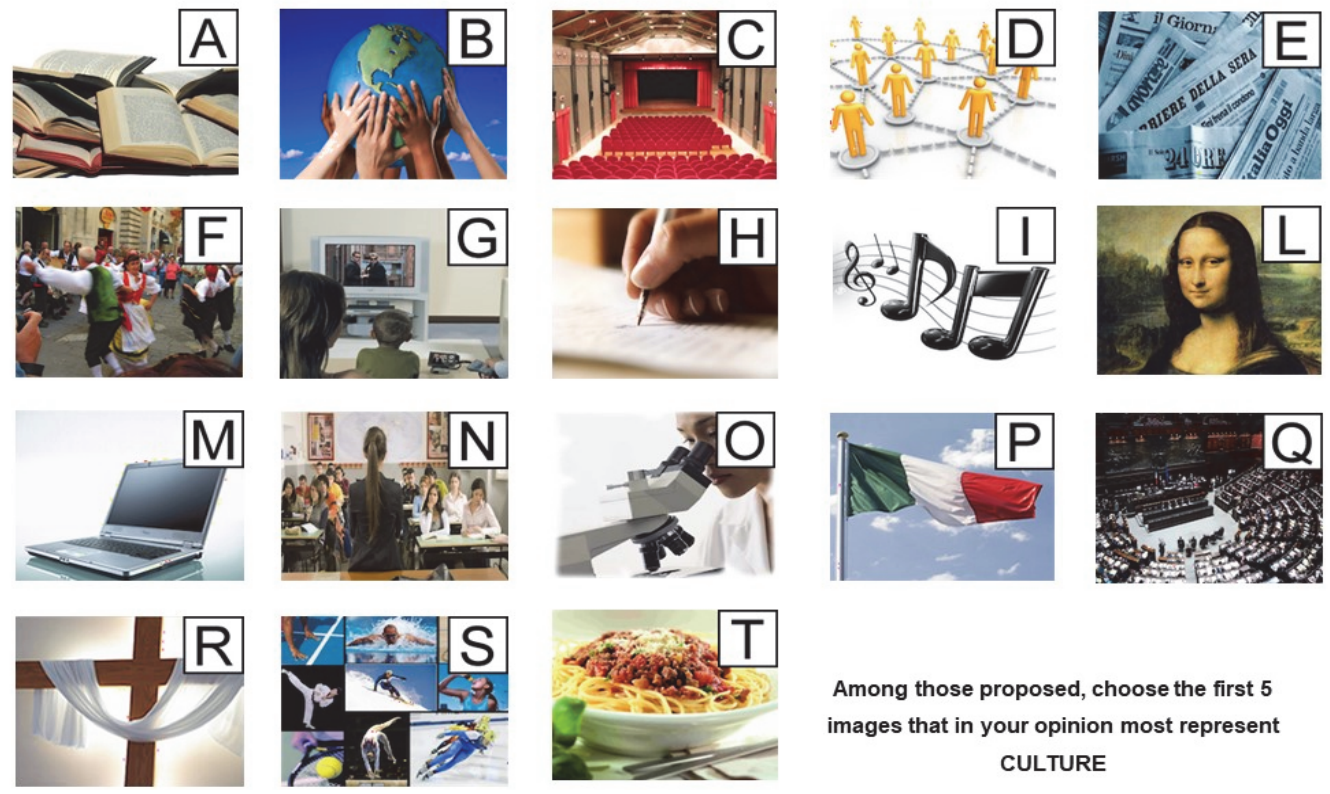

Among those proposed, choose the first 5 images that in your opinion most represent CULTURE

Figure 2. Iconographic stimuli (Galli, Fasanelli, Schember, 2018)

The methodological strategy described above shows the possibility of identifying the iconographic dimension of each central element, which cannot necessarily be evoked by the participants. Moreover, the use of the subjective choice motivation within the questionnaire offers the researcher the possibility of clearly understanding the meaning of each icon associated with the stimulus in a wide number of cases: when the icon might suggest other meanings, when cases the icon seems to be completely unrelated to the inducing term, when an icon is used with a double meaning to understand the articulation of the reasoning underlying its selection, or when the subjective meaning attributed to the icon itself is the focus.

\section{Concluding remarks}

There is a widespread belief that the language of images is more natural and spontaneous than the language of words and that words are learned, and figures recognized naturally, but this belief is completely unfounded. Languages, all languages, are cultural media that allow the senses, affections and intellect to collaborate in the exercising of one's intelligence. Verbal language and the language of images are both legitimately definable as media insofar as they do not merely transcribe the products of thought but are themselves a thought and the work of thought. 
An image, according to Cacciari (2017), has the great power to attract to itself the very objects depicted, a power that a word often does not possess. Civilization has needed, since the beginning of time, physical and, more importantly, mental representations. Even the most abstract thoughts of humankind need representation along a sensitive and aesthetic dimension. It is images that should make people reflect and help them think about issues concerning the fundamental aspects of everyday life.

Jean François Lyotard (2008), in the book Discourse, Figure, argues the need to integrate words and images to reveal and overcome the deception of a model of thought and knowledge based only on a language of words. Having at one's disposal a wealth of quality images capable of interacting and collaborating with words serves mainly to help one look and think about oneself and the world with greater clarity and lucidity.

Neuroscience studies, as Dallari (2018) points out, have shown the partial distinguishability of areas of the brain devoted to image processing from those involved in linguistic processes. However, this does not justify a cultural and epistemological separation of the two categories since, from the point of view of the construction of knowledge, representation, thought and intersubjective relations, these different areas are interconnected. However, it is precisely scholars and researchers from the cognitive area who support the superiority of the universe of images over that of words in the creation of knowledge and representation in the contemporary world. Gottfried Boehm (2009) uses the term iconic turn to indicate what he believes is a real change in characterizing the contemporary world through images.

Psychosocial reflection on these issues includes the work of Moliner (2008), who argues that the social image of an object is the result of a process of activation of multiple mental images obtained through sensitive experiences related to the object through communication with different social groups with which the individual interacts through different media. The latter, today, are much more numerous than the sources of diffusion evoked by Serge Moscovici in the second half of the last century. Today, the individual is "captured" by a society governed by the screen. These screens come in many forms: televisions, computers, tablets and even smartphones. These new forms of communication, whose "medium is the message", are likely to have a major impact on the process of objectification, giving a collective character to the mental images of social groups. It now seems difficult to study social phenomena without iconographic techniques. One could, in fact, reproach the methodologies generally employed that distance themselves from the object of study. We agree with Moliner when he states that it seems difficult to avoid using iconographic techniques for studying social phenomena. Iconographic stimuli, on the other hand, have shown their capacity to unveil the mental images of social groups, showing new and more fruitful relationships not only between subject and object but also, above all, between object and concept. Referring to the seminal work of Moscovici (1961. P. 315), we can say that the "concept is an intellectual instrument that allows to order a series of phenomena and to perceive their relations in an approximate and essential way. The relationship of the concept with reality is neither immediate nor univocal. The leap into the imaginary prepares a fundamental change of status and function. The concept is no longer 
a pure idea or even an image, but an entity. Naturalization draws all its meaning from this insofar as it gives a full reality to what was an abstraction."

It seems evident that what has been described so far is nothing more than a greater and more precise operationalization not only of that generative process of every social representation, called objectification, but, above all, of the original intuition of the existence of a figurative nucleus. The process of objectification, as described by the author of the Social Representations Theory, "seems to break down into two distinct phases or cover two converging movements: one goes from theory to its image, the other goes from this to the construction of social reality. The first phase is that in which the scientific conception, compared to other value systems and other representations, sees a choice being made between its elements; their movement to a concrete level is concomitant. The result is certainly not an aggregation of separate data, but an ordered, coherent and relatively correct whole. At the end of this stage, the theory is found schematized in a twofold sense of a complete selection and stylization of its terms. In this way the imaginative nucleus of a social representation, or figurative model, is constituted... From the scientific theory to the figurative model, the content is schematized and allows some concrete elements to be isolated. In turn, these elements are generalized in a double direction: social, as categories that orient reality, and psychological, as general forms that reflect reality. These two directions are inseparable" (Moscovici, 1961. P. 336).

Italo Calvino (as cited in Dallari, 2018), reflecting on his own work as a story inventor, writes, "We can distinguish two types of imaginative processes: the one that starts from the word and arrives at the visual image and the one that starts from the visual image and arrives at verbal expression". Calvino also points out that "in the conception of a story, the first thing that comes to my mind is an image and for some reason it presents itself to me as full of meaning, even if I do not know how to formulate this meaning in discursive or conceptual terms... it is the images themselves that develop their implicit potential, the story they carry within themselves" (Calvino, 1988. P. 93). For Italo Calvino, thinking words (to say them, to write them) is a process that constantly dialogues with the visual image even when it is not visible in the text: a story is often conceived starting from an image or a series of images born in the author's mind and then generates images in the mind of the reader or the listener.

The work presented in this article, carried out in first person by the writer, as well as by other authors focusing their efforts on this direction, show that this process, admirably described by Calvino, can be completely superimposed upon the one that common sense, the so-called collective mind, carries out whenever it has to deal with an unknown and, for this reason, disturbing phenomenon. New and more articulated studies will be able to support heuristic evidence that thus far seems to be configured as a suggestive hypothesis, which, in any case, will require wider and shared interdisciplinary effort.

\section{References}

Abric, J.-C. (1987). Coopération, compétition et représentations sociales. Cousset: Del Val. Barale, A. (2009). La malinconia dell'immagine: rappresentazione e significato in Walter Benjamin e Aby Warburg. Firenze: Firenze University Press. 
Boehm, G. (2009). La svolta iconica. Modernità, identità, potere. Roma: Meltemi.

Cacciari, M. (2017). Generare Dio. Bologna: il Mulino.

Calvino, I. (1988). Lezioni americane. Milano: Garzanti.

Dallari, M. (2018). Dire le immagini, vedere le parole. Metafore e figure della competenza emotiva. Encyclopaideia, 22(50), 1-20.

Darras, B. (1998). L'image, une vue de l'esprit. Etude comparée de la pensée figurative et de la pensée visuelle. Recherches en communication, 9, 77-99.

Rosa, A. S. de, \& Farr, R. (2001). Icon and Symbol: Two Sides of the Coin in the Investigation of Social Representations. In F. Buschini \& N. Kalampalikis (Eds.), Penser la vie, le social, la nature. Mélanges en hommage à Serge Moscovici (pp. 237-256). Paris: Les Editions de la MSH.

Fasanelli, R., Galli, I., \& Piscitelli, A. (2020). Social Representations of Covid-19 in the Framework of Risk Psychology. Papers on social representations. 29(2), 8.1-8.36. Retrieved March 1, 2021, from http://psr.iscte-iul.pt/index.php/PSR/index

Fasanelli, R., Galli, I., Riverso, R., \& Piscitelli, A. (2020). Social Representations of Insects as Food: An Explorative-Comparative Study among Millennials and X-Generation Consumers. Insects, 11(10), 656. https://doi.org/10.3390/insects11100656

Galli, I. (Ed.). (2008). Del potere e di altri demoni. Napoli: Edizioni Scientifiche Italiane.

Galli, I., \& Fasanelli, R. (2020) Public Understanding of Science and Common Sense: Social representations of the human microbiome among the expert and non-expert public. Health Psychology Open, 7(1), 1-14. https://doi.org/10.1177/205510292091323

Galli, I., \& Nigro, G. (1989). L'uso di stimoli prototipici nello studio delle rappresentazioni sociali, Psicologia Italiana, 10(1), 13-20.

Galli, I., Fasanelli, R., \& Schember, E. (2018). The construction of icons as a means of access to the social representation of culture. Culture \& Psychology, 24(2), 212-232.

Galli, I., Liguori, A., Lorenzi-Cioldi, F., \& Fasanelli, R. (2019). Men, Women, and Economic Changes: Social Representations of the Economic Crisis. Interdisciplinaria, 36(2), 283-298. https://doi.org/10.16888/interd.2019.36.2.18

Lyotard, J.F. (2008). Discorso, figura. Milano: Mimesis.

Mitchell, W.J.T. (2005). What is an Image? New Literary History, 15(3), 503-537.

Molinari, L., \& Emiliani, F. (1990). What is an image? The structure of mothers' images of the child and their influence on conversational styles. In G. Duveen \& B. Lloyd Bloom (Eds.), Social representations and the development of knowledge (pp. 91-106). Cambridge: Cambridge University Press. https://doi.org/10.1017/CBO9780511659874.006

Moliner, P. (1996). Images et représentations sociales. Grenoble, France: Presses Universitaires de Grenoble.

Moliner, P. (2008). Représentations sociales et Imagerie Mentale. Communication et Organisation, 34, 13-24. https://doi.org/10.4000/communicationorganisation.547

Moliner, P. (2016). Psychologie sociale de l'image. Grenoble, France: Presses Universitaires de Grenoble.

Moscovici, S. (1961). La psychanalyse, son image et son public. Paris: Presses Universitaires de France.

Warburg, A. (1896-1901). Symbolismus al Umfangsbestimmung (WIA, III.45.1 e III.45.2, p. 23).

\section{Article history:}

Received: 1 March 2021

Revised: 30 March 2020

Accepted: 15 April 2021

\section{For citation:}

Galli, I., \& Fasanelli, R. (2021). From prototypical stimuli to iconographic stimuli: The power of images in the study of social representations. RUDN Journal of Psychology and Pedagogics, 18(2), 391-401. http://dx.doi.org/10.22363/2313-1683-2021-18-2-391-401 


\title{
Bio notes:
}

Ida Galli, Ph.D., is Full Professor of Social Psychology at the Department of Social Sciences of the University of Naples Federico II (Naples, Italy). She was Directeur d'Etudes Associée at the Maison des Sciences de l'Homme in Paris. Currently she's the Director of the Mediterranean Centre for the Study of Social Representations associated to the REMOSCO (Reseau Mondial Serge Moscovici). She authored scientific books and over a hundred papers published on specialized journals. Her research interests lie mainly in the theoretical framework of social representations and were also devoted to psychological androgyny and correlational studies on gender and Machiavellianism, anxiety, locus of control and interindividual power strategies. ORCID iD: https://orcid.org/0000-00015159-9162. E-mail: idagalli@unina.it

Roberto Fasanelli, Ph.D. in Health Psychology, individual and social risk prevention, is an Assistant Professor of Social Psychology and Risk Psychology at the Department of Social Sciences of the University of Naples Federico II. He was Visiting Professor at the Alexandru Ioan Cuza University (Iaşi, Romania) and at the National University of Colombia (Bogotà). His research interests lie mainly in the epistemo-methodological framework of social representations and were also devoted to social psychology of health, environmental psychology, risk psychology and evaluative research. He's also a consultant to ONGs/public administrations, team building trainer for start-uppers and a social workers trainer on gender gap issues. ORCID iD: https://orcid.org/0000-0001-8908-3284. E-mail: roberto.fasanelli@unina.it

DOI 10.22363/2313-1683-2021-18-2-391-401

Теоретическая статья

\section{От прототипических к иконографическим стимулам: потенциал образов в изучении социальных представлений}

\author{
И. Галли $\mathbb{D}^{\circledR}$, Р. Фазанелли \\ Неаполитанский университет имени Фридриха II, \\ Итальянская Республика, 80138, Неаполь, Vico Monte della Pietà, d. 1 \\ idagalli@unina.it
}

Аннотация. Когда психологов интересует образ социального объекта, они изучают, что люди думают об этом объекте, как восприняли его, как проинтерпретировали это восприятие. Полностью соглашаясь с идеей о том, что применение иконографических стимулов может усилить традиционные методы, приемы и техники, которые используются для изучения социального представления, в настоящем исследовании авторы представили две техники: 1) прототипических стимулов, предложенную во второй половине 1980-х годов Галли и Нигро; 2) иконографических стимулов, творчески интегрирующую образы и слова в единый инструмент, недавно разработанную Галли, Фазанелли и Шембером для изучения социального представления о культуре. Исследования, обзор которых представлен в статье, ясно демонстрируют, что образ обладает огромной притягательной силой, силой, которую часто не имеет слово. Именно образы заставляют людей задуматься, помогают им размышлять над вопросами, касающимися фундаментальных аспектов повседневной жизни. Предложенная в статье разработка мультиметодического подхода к исследованию социальных представлений является лишь от- 
правной точкой для размышлений, новые и более четко организованные исследования смогут подкрепить эвристическими доказательствами то, что пока выглядит как гипотеза, которая в любом случае потребует более широких и совместных междисциплинарных усилий.

Ключевые слова: социальные представления, прототипические стимулы, иконографические стимулы, мультиметодический подход

\section{История статьи:}

Поступила в редакцию: 1 марта 2021 г.

Принята к печати: 15 апреля 2021 г.

\section{Для цитирования:}

Galli I., Fasanelli R. From prototypical stimuli to iconographic stimuli: the power of images in the study of social representations // Вестник Российского университета дружбы народов. Серия: Психология и педагогика. 2021. Т. 18. № 2. С. 391-401. http://dx.doi.org/10.22363/2313-1683-2021-18-2-391-401

\section{Сведения об авторах:}

Галли Ида, Ph.D., профессор социальной психологии департамента социальных наук Неаполитанского университета имени Фридриха II (Неаполь, Италия). Занимала должность директора по научным исследованиям в Доме науки в Париже. В настоящее время является директором Средиземноморского центра изучения социальных представлений, связанного с REMOSCO (Reseau Mondial Serge Moscovici). Автор нескольких монографий и более ста статей, опубликованных в специализированных журналах. Ее исследовательские интересы в основном связаны с теорией социальных представлений, а также с изучением психологической андрогинности, гендера и макиавеллизма, тревожности, локуса контроля и стратегий межиндивидуальной власти. ORCID iD: https://orcid.org/0000-0001-5159-9162. E-mail: idagalli@unina.it

Фазанелли Роберто, Ph.D. в области психологии здоровья, предотвращения индивидуальных и социальных рисков, доцент кафедры социальной психологии и психологии риска департамента социальных наук Неаполитанского университета имени Фридриха II (Неаполь, Италия). Был приглашенным профессором в Ясском университете имени А.И. Кузы (Румыния) и в Национальном университете Колумбии (Богота). Его исследовательские интересы в основном связаны с эпистемометодологической структурой социальных представлений, а также посвящены социальной психологии здоровья, психологии окружающей среды, психологии риска и оценочным исследованиям. Он также является консультантом ONG/органов государственного управления, ведущим тренингов по командообразованию для стартаперов и ведущим тренингов для социальных работников по проблемам гендерного разрыва. ORCID iD: https://orcid.org/0000-0001-8908-3284. E-mail: roberto.fasanelli@unina.it 